\section{ISSN 24546348}

tics publications

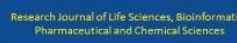

$\lim _{0}=$

htep://muwerylopes.com/

Original Research Article

Research Journal of Life Sciences, Bioinformatics,

Pharmaceutical and Chemical Sciences

Journal Home page http://www.rjlbpcs.com/
RJLBPCS

RJLBPCS

ISSN 2454-6348

ANTIMICROBIAL, ANTI-ADHESION AND ANTI-BIOFILM ACTIVITY

OF BIOSURFACTANT ISOLATED FROM LACTOBACILLUS SPP. Nagea Abdalsadiq ${ }^{1}$, Zaiton Hassan ${ }^{1 *}$, Mohd Lani ${ }^{2}$

1.Department of Microbiology, Faculty of Science and Technology, Universiti Sains Islam Malaysia (USIM), 71800 Nilai, Negeri Sembilan, Malaysia.

2. School of Food Science and Technology, Universiti Malaysia Terengganu (UMT), 21030 Kuala Terengganu, Terengganu, Malaysia.

\begin{abstract}
Biosurfactants are biological surface active compounds released by microorganisms. The application of biosurfactant in food industry to remove adhering microorganisms will reduce the occurrence of food spoilage and food poisoning. The purpose of this study was to evaluate the antimicrobial, anti-adhesive and anti-biofilm activity of biosurfactants (lipopeptide and glycolipid fractions) produced by L. acedophillus and L. pentousus . Antimicrobial, antiadhesion and antibiofilm activity against P. mirabilis, S. aureus, S. pneumonia, and K. Pneumoniae and C. albicans were assessed using the disc diffusion method, antiadhesion and antibiofilm assay. The lipopeptide fraction exhibited stronger antimicrobial at lower MIC values a ranging from 7,81 to $62.5 \mu \mathrm{g} / \mathrm{ml}$ while glycolipid fraction exhibited bioactivity against pathogenic bacteria at MIC values a ranging from 15.6 to $62.5 \mu \mathrm{g} / \mathrm{ml}$. Biosurfactant fractions showed strong antiadhesion activity against pathogens ranging from 65 to $93 \%$ by lipopeptide fraction and 45 to $72.7 \%$ by glycolipid fraction. The lipopeptide fraction showed a higher biofilm inhibition a ranged from 85.3 to $100 \%$ at a concentration of $250 \mu \mathrm{g} / \mathrm{ml}$ while the glycolipid fraction caused biofilm inhibition a ranged from 31.7 to $100 \%$ at the same concentration. New strategies are required to overcome extreme biofilm antibiotic resistance by development of novel therapies aimed at disrupting biofilms and killing the constituent bacteria, Therefore, the treatment with biosurfactant of L. acedophillus and L. pentousus could be, provide an optional way for controlling biofilm development and also influence the adhesion ability of pathogens.
\end{abstract}

KEYWORDS: Lactobacillus, Lipopeptide, Glycolipid, Antimicrobial, Antiadhesion, Antibiofilm.

(C) 2018 Life Science Informatics Publication All rights reserved Peer review under responsibility of Life Science Informatics Publications 


\section{Corresponding Author: Dr. Zaiton Hassan* Ph.D}

Department of Microbiology, FST, USIM, 71800 Nilai, Negeri Sembilan, Malaysia.

Email Address: drzaiton@gmail.com

\section{INTRODUCTION}

Biosurfactant $\mathrm{s}$ is amphipathic molecules and mainly excretions by micro-organisms outside the cells, and sometimes attached to the cells, mostly during growth on water immiscible substrates. They have both hydrophilic and hydrophobic parts. Hydrophilic parts can comprise amino acids or peptides, phosphate, alcohol and mono- di- or poly-saccharides. Hydrophobic parts comprise unsaturated or saturated fatty acids [1]. Biosurfactant s prefer to proliferate at the point where fluid phases interface with various polarity. They are capable of reducing surface and interfacial tension [1]. Biosurfactant s can potentially be utilised as therapeutic agents because they are safe and have antibacterial, antifungal, and antiviral functions. They disturb the membranes which results in an increase of the membrane permeability, followed by cell lysis and loss of metabolites. These compounds are able to affect adhesion properties of microorganisms, by partitioning at the interfaces [2]. Probiotics have been known to alter the adhesive ability of other bacteria through the production of biosurfactant s able to modify hydrophobic interactions [3]. Gan et al [4] found that a biosurfactant containing collagen binding proteins derived from L. fermentum RC-14 was able to inhibit staphylococcal binding to surgical implants. It is generally recognised that biosurfactant s prevent pathogenic organisms from adhering to solid surfaces and infection sites. Rodrigues et al [2] described specific anti-adhesive-activities of rhamnolipids derived from $P$. aeruginosa, glycolipids that originated from $S$. thermophilus and surfactants derived from L. lactis against many bacterial and yeast strains isolated from voice prostheses. A study by Gan et al. [4] analysed the use of L. fermentum RC-14 and L. rhamnosus GR-1 on a silicone surgical implant model in rats. L. fermentum and its associated biosurfactant could inhibit surgical implant infection with $S$. aureus, the first evidence that a probiotic strain may be useful in combating infections in vivo. Biosurfactant s can potentially be used for interfering with biofilm formation because they alter the microbial interaction with interfaces [5, 6]. Biofilms are organised microbial communities bound to a surface. Separate micro-bound organisms in biofilms are entrenched in a matrix of usually slimy extracellular polymers, and typically show a phenotype that is varies distinctly from that of planktonic cells [7]. The majority of micro-organisms are present in biofilms bound to surfaces and not as planktonic (free-living) organisms. They are protected from stress factors and can survive in non-optimal conditions [8]. Another characteristic of biofilms is their lower susceptibility to antimicrobial agents compared to planktonic forms. Clinical importance are antifungal agents like amphotericin B, fluconazole, flucytosine, itraconazole, and

(C) 2018 Life Science Informatics Publication All rights reserved Peer review under responsibility of Life Science Informatics Publications 
ketoconazole, which seem to be less active against $C$. albicans biofilms than against planktonic cells [9].

\section{MATERIALS AND METHODS}

\section{Antimicrobial activity of biosurfactant fractions}

The fraction A from L. acedophillus and L. pentousus which were purified by column chromatography were selected in the present investigation for their highest ST reduction compared with other fractions. These fractions were purified, dried, and weighted. The stock solutions of TLC purified active fractions (fractions A, B and C) were prepared in PBS. For this $1 \mathrm{mg} / \mathrm{ml}$ of the solution was prepared in PBS. The solution was filtered through a $0.22-\mu$ m nylon membrane filter (Whatman, Maidstone, Kent, \& UK) and stored separately in sterile glass vials to be utilised for the antimicrobial tests [10].

\section{Test Microorganisms}

The bacteria strains urilised in this study included Proteus mirabilis ATCC 12453 S. aureus, $S$. pneumoniae ATCC 13048, K. Pneumoniae ATCC 10031 and C. albicans.

\section{Preparation Of Pathogenic Microorganism}

The pathogenic bacteria used in this study were obtained from the Microbiology Laboratory, Universiti Sains Islam Malaysia, and Universiti Kebangsaan Malaysia. The bacteria were grown on nutrient agar (Oxoid, UK) and nutrient broth (Oxoid, UK) at $37^{\circ} \mathrm{C}$ for $24 \mathrm{~h}$ and then kept at $4^{\circ} \mathrm{C}$ for later experiments. Bacterial test strains were subjected to culturing overnight in nutrient broth at $37^{\circ} \mathrm{C}$. A $16-\mathrm{h}$ culture was diluted with a sterile physiological saline solution [PS: $0.85 \%(\mathrm{w} / \mathrm{v})$ sodium chloride] with reference to the $0.5 \mathrm{McFarland}$ standards to achieve an inoculums size of approximately $10^{8}$ colony-forming units $\mathrm{mL}^{-1}\left(10^{8} \mathrm{CFU} \mathrm{m}{ }^{-1)}\right.$. The OD of these broth cultures was adjusted to 0.1 (equivalent to inoculums of $10^{8} \mathrm{CFU} \mathrm{ml}^{-1}$ ) [10].

\section{Evaluation Of Antimicrobial Activity By Disc Diffusion Method}

How susceptible the test strains were against biosurfactant was tested using the disc diffusion technique conducted on Mueller-Hinton agar (MHA) plates and Patato dextrose agar (PDA) plates for pathogenic bacteria and fungi respectively. This was done by determining the inhibition zones $(\mathrm{mm})$ in Mueller-Hinton agar. Samples of biosurfactant fraction were dissolved in sterile PBS to achieve a concentration of $50 \mu \mathrm{g} / \mathrm{mL}$. Sterile discs of $9 \mathrm{~mm}$ were soaked in this solution and dried after every soaking step. Nutrient broth tubes were inoculated with tested organisms and the bacterial/fungal suspension was modified accordingly to match the tube of $0.5 \mathrm{McFarland}$ turbidity standards using the spectrophotometer at $660 \mathrm{~nm}$, which equals $10^{8} \mathrm{CFU} \mathrm{ml^{-1 }}$. A precise amount of $500 \mu 1$ of suspension was utilised to inoculate MHA and Patato plates by flooding their surface and spreading them uniformly on plates. The discs were then placed over the bacteria/fungal lawn onto MHA/ PDA and pressed gently. The plates were then subjected to incubation at $37^{\circ} \mathrm{C}$ for $24 \mathrm{hrs}$ and then the microbial growth inhibition zones around the discs were recorded. All tests

(C) 2018 Life Science Informatics Publication All rights reserved Peer review under responsibility of Life Science Informatics Publications 
were carried out in triplicate. Amoxicillin was used as [11].

\section{Determination Of Minimal Inhibitory Concentration (MIC)}

The MIC was defined as the lowest concentration that induced no observable growth. MIC was calculated on bacterial strain that exhibited sensitivity to the purified biosurfactant fractions in the disc diffusion method. As mentioned in Section 7.2.1, stock solution of biosurfactant fractions was prepared by dissolving these fractions in PBS to achieve a final solution of $1000 \mu \mathrm{g} / \mathrm{mL}$. Following that, $250 \mu \mathrm{l}$ of sterile biosurfactant fractions' solution was added to the first column of the 96-well microplate, and $125 \mu \mathrm{l}$ of sterile Mueller-Hinton broth medium in the remaining wells. Then, $125 \mu \mathrm{l}$ of Fractions' solution from the first column was moved to the second column and mixed with the medium. In the same way, $125 \mu$ was moved to the subsequent wells, removing $125 \mu \mathrm{l}$ of the mixture in the $10^{\text {th }}$ column, to have a final volume $125 \mu \mathrm{l}$ for all wells. This process resulted in two-fold serial dilutions of the biosurfactant fractions in the first 10 columns (1.95, 3.90, 7.81, 15.6, 31.2, 62.5, 125, $250 \mu \mathrm{g} / \mathrm{mL}$ ). Columns 11 and 12 did not have biosurfactant fractions and served as positive and negative controls, respectively. All the wells were inoculated with $125 \mu \mathrm{L}$ of the inoculums which were prepared after $12 \mathrm{hrs}$ incubation at $37^{\circ} \mathrm{C}$ and then diluted to $0.5 \mathrm{McF}$ arland standard turbidity (a final density of $10^{8} \mathrm{CFU} \mathrm{ml}^{-1}$ ). The microtitre plate was covered with a lid and then incubated overnight at $37^{\circ} \mathrm{C}$. The OD value of each test well was measured immediately at a wavelength of $600 \mathrm{~nm}$ in micro Elisa auto reader (Model 680, BioRad) and compared with the control wells. The OD reading of pathogen without biosurfactant was assigned a value of $100 \%$ growth. The Amoxicillin was used as control. The results are presented as percent of growth inhibition:

$$
\text { Growth inhibition }(\%)=[1-(\mathrm{ODc}) / \mathrm{OD} 0] \times 100
$$

Where:

ODc is the optical density of the well with a biosurfactant concentration c, and pathogen; OD0 is the optical density of the pathogen suspension with no biosurfactant (control). Triplicate assays were conducted and the mean of optical density was taken. MIC of Amoxicillin was evaluated to compare with biosurfactant fractions [12].

\section{Determination Of Anti-Adhesion Activity}

The anti-adhesive activity of the biosurfactant s fractions against target pathogens was performed in co-incubation as described by [12]. The 96-well microtiter plates were coated with $200 \mu \mathrm{l}$ of biosurfactant fraction solutions prepared in PBS at different concentrations $(1.95,3.90,7.81,15.6$, $31.2,62.5,125,250 \mu \mathrm{g} / \mathrm{mL}$ ) and the microtiter plates were subjected to incubation at $37^{\circ} \mathrm{C}$ for 24 hrs. Following this, the biosurfactant solution was removed and the plate rinsed twice with 100 $\mu \mathrm{l}$ of PBS pH 7.2 to eliminate non-adhering biosurfactant. The next step was the addition of 150 $\mu \mathrm{l}$ of a washed bacterial and candida suspension in PBS, adjusting it to $0.5 \mathrm{McFarland}$ standard

(C) 2018 Life Science Informatics Publication All rights reserved Peer review under responsibility of Life Science Informatics Publications 
Abdalsadiq et al RJLBPCS $2018 \quad$ www.rjlbpcs.com

Life Science Informatics Publications turbidity (a final density of $10^{8} \mathrm{CFU} \mathrm{m}^{-1}$ ) to individual wells after which the microtiter plate was again subjected to incubation at $37^{\circ} \mathrm{C}$ for $24 \mathrm{hrs}$. No adhering cells were eliminated by gently rinsing twice the wells with PBS $\mathrm{pH}$ 7.2. Quantification was done using the crystal violet assay [13]. The biofilm was mixed for 15 min following the addition of $100 \mu 1$ of $99 \%$ methanol to each well and the plate was then air-dried. In the next step, $100 \mu \mathrm{l}$ of crystal violet $2 \%$ was added and held for 20 min prior to the removal of the superfluous crystal violet by pipetting and, the residue in the wells was rinsed with tap water. The stain bound to the adherent pathogens was solubilised with $100 \mu \mathrm{l}$ of $33 \%$ glacial acetic acid for each well and the optical density readings of individual wells were recorded at $595 \mathrm{~nm}$ employing micro Elisa auto reader (Model 680, BioRad). This was followed by the preparation of Bacterial and candida suspension with no biosurfactant, as control. The percentage of adherence reduction was computed with the formula of Gudina et al. (2010)

Microbial antiadhesion $(\%)=[1-(\mathrm{ODc}) / \mathrm{OD} 0] \times 100$

Where:

ODc is the optical density of the well with a biosurfactant concentration $\mathrm{c}$ and pathogen, and OD0 is the optical density of the pathogen suspension with no biosurfactant (control). Triplicate assays were conducted and the mean of optical density was taken.

\section{Determination Of Anti-Biofilm Formation}

The anti-biofilm activity of the biosurfactant $\mathrm{s}$ fractions against target pathogens was performed as described by [12]. Briefly, an aliquot of $150 \mu 1$ of a washed bacterial suspension in PBS adjusted

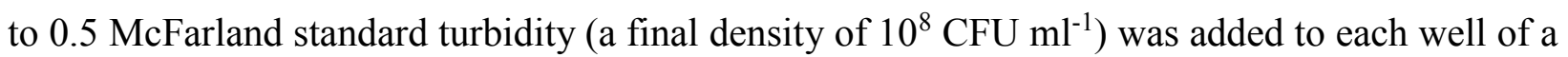
sterile 96-well microtiter plate together with $200 \mu 1$ of biosurfactant fraction solutions prepared in PBS at different concentrations $(1.95,3.90,7.81,15.6,31.2,62.5,125,250 \mu \mathrm{g} / \mathrm{mL})$. Control wells contained PBS and bacterial suspension without biosurfactant solution. Free microorganisms were eliminated by rinsing the wells twice with PBS pH 7.2. The microorganisms still adhering were fixed with $200 \mu \mathrm{l}$ of $99 \%$ methanol per well. The plates were emptied after 15 minutes and allowed to dry. The next step involved staining the plates for 20 min with $100 \mu 1$ of $2 \%$ crystal violet (used for Gram staining) per well. The wells were then washed three times with PBS pH 7.2 to eliminate excess stain. The plates were air-dried followed by re-solubilising of the dye bound to the adherent microorganisms with $200 \mu \mathrm{l}$ of $33 \%$ (v/v) glacial acetic acid per well and the optical density of each well was recorded at $595 \mathrm{~nm}$ in micro Elisa auto reader (Model 680, BioRad). Anti-biofilm activity of biosurfactant fractions was determined based on the following formula:

$$
\text { Anti-biofilm activity }(\%)=[1-(\mathrm{ODc}) / \mathrm{OD} 0] \times 100
$$

Where:

ODc is the optical density of the well with a biosurfactant concentration c and pathogen; OD0 is the optical density of the pathogen suspension with no biosurfactant (control). Triplicate assays

(C) 2018 Life Science Informatics Publication All rights reserved

Peer review under responsibility of Life Science Informatics Publications 

was conducted and the mean of optical density was taken.

\section{Statistical Analysis}

Results were shown as the mean \pm standard deviation and all measurements were done in triplicate. A one-way ANOVA $(\mathrm{P}<0.05)$ applying the Tukey multiple-comparisons using SPSS software was used for the evaluation of the. Statistically significant differences of the conditions tested in the different assays. There was a significant difference if $\mathrm{P}<0.05$.

\section{RESULTS AND DISCUSSION}

The biosurfactant fractions prepared with chloroform: methanol obtained from Lactobacillus sp. was purified by silica gel column, and collected fractions were used to perform biological tests. The fraction A from L.acedophillus and L. pentousus had more effective compounds than other fractions (high ST reduction).

\section{Antimicrobial Activity By Disc Diffusion Method}

Lipopeptides and glycolipids are the best known class of biosurfactants with antimicrobial effects. The biosurfactants, such as lipopeptides and rhamnolipids, showed an inhibiting activity against bacteria and fungi $[14,15]$. This study showed that the biosurfactant fractions were an effective agent in controlling bacterial growth of gram positive, gram negative and fungus. The inhibition zone diameter ranged from $14.00 \mathrm{~mm}$ to $44.00 \mathrm{~mm}$ for lipopeptide fraction, 5.00 to 40.43 for glycolipid fraction and they were significantly different $(p<0.05)$ from Amoxicillin (8.50 to 14.30 $\mathrm{mm})$. These results suggest that biosurfactant fractions are effective in limiting the growth of $P$. mirabilis and C. albicans, which are resistant to Amoxicillin (Table 1 and Figure-1). In addition, the lipopetide fraction is more effective against pathogenic bacteria and fungus than the glycolipid fraction. Although the cell walls of gram negative bacteria are usually resistant to lipophilic solutes because they consist of a peptidoglycan layer and an additional outer membrane (narrow outer wall) rather than gram-positive bacteria cell walls, which contain peptidoglycan (loose outer wall), which makes gram positive more sensitive [16]. This may be because lipopeptide biosurfactant causes loss or damage of the peptidoglycan layer may also inhibit the biochemical reactions in the cell wall and prevent peptidoglycan growth. The lipopeptide fraction showed high antimicrobial activity against $C$. albicans which may reflect its effect on the fungal membrane by disorganising the fungal membrane or preventing the cell wall from synthesising. 
Table 1: Growth inhibition zone $(\mathrm{mm})$ of pathogens by biosurfactant using disc diffusion method

\begin{tabular}{ccccc}
\hline Pathogens & Lipopeptide & Glycolipid & Amoxicillin & PBS \\
\hline P. mirabilis & $27.15 \pm 0.23^{\mathrm{dA}}$ & $22.00 \pm 0.53^{\mathrm{bB}}$ & $0^{\mathrm{cC}}$ & $0^{\mathrm{aC}}$ \\
S. aureus & $44.00 \pm 0.05^{\mathrm{aA}}$ & $40.43 \pm 0.00^{\mathrm{aA}}$ & $14.30 \pm 0.53^{\mathrm{aB}}$ & $0^{\mathrm{aC}}$ \\
S. pneumoniae & $38.00 \pm 0.20^{\mathrm{bA}}$ & $0.00 \pm 0.00^{\mathrm{dC}}$ & $8.50 \pm 0.03^{\mathrm{bB}}$ & $0^{\mathrm{aC}}$ \\
K. Pneumoniae $^{\text {P. }}$ & $14.00 \pm 0.05^{\mathrm{eA}}$ & $5.00 \pm 2.08^{\mathrm{cB}}$ & $10.50 \pm 0.81^{\mathrm{abA}}$ & $0^{\mathrm{aC}}$ \\
C. albicans $^{\mathrm{aC}}$ & $32.12 \pm 0.23^{\mathrm{cA}}$ & $6.00 \pm 0.53^{\mathrm{cB}}$ & $0^{\mathrm{aC}}$ & $0^{\mathrm{aC}}$ \\
\hline
\end{tabular}

Different letters in the same column (lower case) and in the same row (upper case) represents significant differences at $\mathrm{p}<0.05$

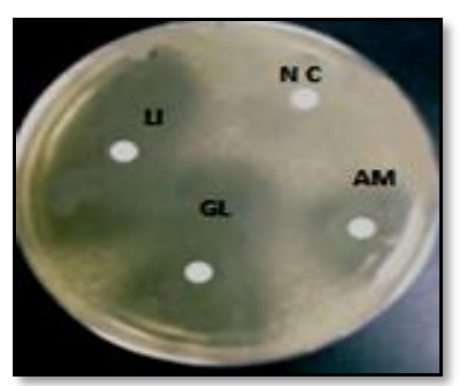

S.aureus

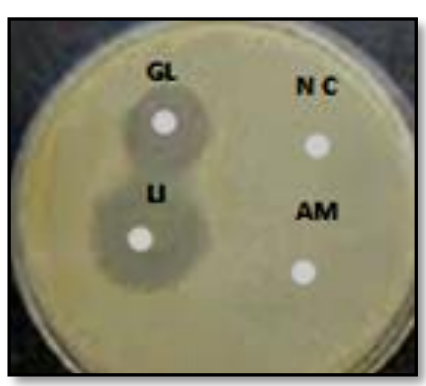

P. mirabilis

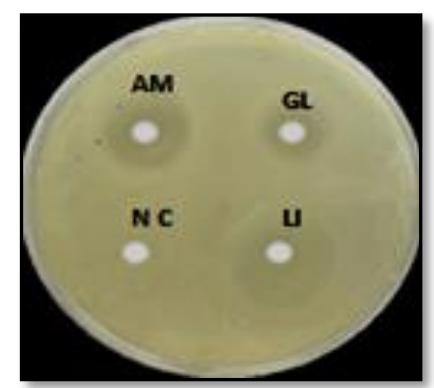

K. Pneumoniae

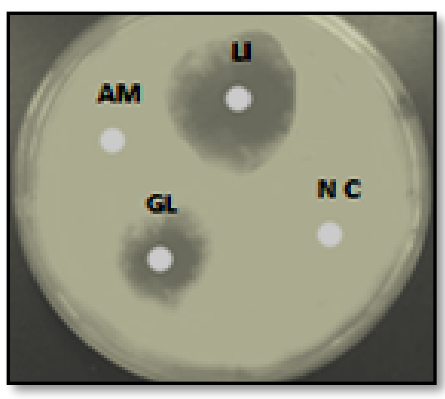

C. albicans

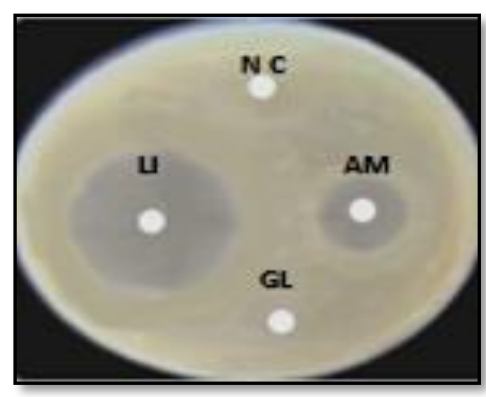

S. pneumoniae

Figure: 1 Inhibitory zone of biosurfactant against pathogens.LI. Lipopeptide, GL. Glycolipid,

AM. Amoxicillin, NC. negative control

\section{Minimum Inhibition Concentration (MIC)}

MIC of lipopeptide fraction ranged from $7.81 \mu \mathrm{g} / \mathrm{ml}$ to $62.5 \mu \mathrm{g} / \mathrm{ml}$, glycolipid fraction ranged from $15.6 \mu \mathrm{g} / \mathrm{ml}$ to $62.5 \mu \mathrm{g} / \mathrm{ml}$ and they are significantly different $(p<0.05)$ from Amoxicillin (125.00 $\mu \mathrm{g} / \mathrm{ml}$ to $250 \mu \mathrm{g} / \mathrm{ml})$. The concentration of $250 \mu \mathrm{g} / \mathrm{ml}$ matches the bacterial growth of $K$. Pneumoniae using Amoxicillin as reference. Also, when tested against S. pneumonia, the MIC value was $250 \mu \mathrm{g} / \mathrm{ml})$. At $125 \mu \mathrm{g} / \mathrm{ml}$ concentration of Amoxicillin, it inhibited S. aureus. On the other hand, complete growth inhibition by lipopeptide fraction against P. Mirabilis, C. albicans S. pneumonia, S. aureus and $K$. Pneumoniae, was at concentrations of 7.81, 7.81, 7.81, 15.6 and $62.5 \mu \mathrm{g} / \mathrm{ml}$ compared to Amoxicillin (no inhibition, no inhibition, 250, 125 and $250 \mu \mathrm{g} / \mathrm{ml}$ ) respectively. Generally, the MIC of lipopeptide biosurfactant against all pathogens is very low compared to Amoxicillin which reflects its potent inhibitory activity against test pathogens (Table

(C) 2018 Life Science Informatics Publication All rights reserved

Peer review under responsibility of Life Science Informatics Publications 
2). Gudina et al [12] reported that the MIC of biosurfactants obtained from L. paracasei against $E$. coli, S. aureus, S. epidermidis and S. agalactiae was between 25 and $50 \mathrm{mg} / \mathrm{ml}$. In this study, the glycolipid fractions completely inhibited the growth of K. Pneumoniae, C. albicans, S. aureus and P. mirabilis at very low concentrations of $15.6,31.2$ and $62.5 \mu \mathrm{g} /$ respectively, compared to Amoxicillin. Similarly, the biosurfactant isolated from S. thermophilus and L. lactis totally suppressed the development of $S$. aureus and $S$. epidermidis with concentrations of $100 \mathrm{mg} / \mathrm{ml}$ [17]. In agreement with this study, Salman et al [18] noted that the biosurfactant isolated from S. thermophilus showed that it could inhibit Klebsiella spp at MIC of $100 \mu \mathrm{g} / \mathrm{ml}$ compared to lipopeptide $(62.5 \mu \mathrm{g})$ and glycolipid fraction $(15.6 \mu \mathrm{g})$. Results of this study show that the MIC of biosurfactant fractions on different pathogens was lower than those obtained by several previous studies which could be due to the nature of the biosurfactants obtained in the present study since the antimicrobial activity of biosurfactants varies with their nature.

Table 2: MIC $(\mu \mathrm{g} / \mathrm{ml})$ of biosurfactant fractions

\begin{tabular}{cccc}
\hline Pathogen & Lipopeptide & Glycolipid & Amoxicillin \\
& & & \\
\hline P. mirabilis & $7.81 \pm 0.5^{\mathrm{aA}}$ & $62.5 \pm 0.1^{\mathrm{cB}}$ & no inhibition \\
S. aureus $^{\mathrm{bu}}$ & $15.6 \pm 0.7^{\mathrm{bA}}$ & $62.5 \pm 0.1^{\mathrm{cB}}$ & $125 \pm 0.3^{\mathrm{aC}}$ \\
S. pneumoniae & $7.81 \pm 0.5^{\mathrm{aA}}$ & no inhibition & $250 \pm 0.2^{\mathrm{bD}}$ \\
K. Pneumoniae $^{\mathrm{cB}}$ & $62.5 \pm 0.1^{\mathrm{B}}$ & $15.6 \pm 0.7^{\mathrm{aA}}$ & $250 \pm 0.8^{\mathrm{bC}}$ \\
C. albicans & $7.81 \pm 0.5^{\mathrm{aA}}$ & $31.2 \pm 0.4^{\mathrm{bB}}$ & no inhibition \\
\hline
\end{tabular}

Different letters in the same column (lower case) and in the same row (upper case) represents significant differences at $\mathrm{p}<0.05$

\section{Anti-Adhesion Activity Of Biosurfactant Fractions Against Test Pathogens}

The antiadhesion assay estimated the biosurfactant fraction concentrations that could effectively inhibit adhesion of the microorganisms. The lipopeptide fraction showed significant $(\mathrm{p}<0.05)$ antiadhesion activity against all pathogens, ranging from $65 \%$ to $93 \%$, and glycolipid ranging from $45 \%$ to $72 \%$. Results clearly show that the anti-adhesion activity rises as the concentration of fractions increases. Lipopeptide fraction demonstrated a higher anti-adhesion activity against gram positive and gram negative bacteria compared to the Amoxicillin. In addition, the antiadhesion activity of lipopeptide fraction against C. albicans $(89.3 \%)$ was higher than the antiadhesion activity of glycolipid fraction against the same pathogen (72.7\%). The lipopeptide reduced the adhesion of $K$. Pneumoniae by $93 \%$ at concentration $250 \mu \mathrm{g} / \mathrm{mL}$, followed by $S$. aureus, C. albicans, S. pneumonia, and P. mirabilis which were reduced by $92 \%, 89.3,76.3 \%$ and $65 \%$ respectively at the same concentration (Table 3 ).

(C) 2018 Life Science Informatics Publication All rights reserved 
Table 3: Anti-adhesion activity of lipopeptide against test pathogens

\begin{tabular}{cccccc}
\hline $\begin{array}{c}\text { Lipopeptide } \\
(\boldsymbol{\mu g} / \mathbf{m l})\end{array}$ & P.mirabilis & S. aureus $^{\text {P.pneumoniae }}$ & $\boldsymbol{K}^{\text {K. Pneumoniae }}$ & C.albicans \\
\hline 1.95 & $20.0 \pm 0.0^{\mathrm{fB}}$ & $21.6 \pm 0.0^{\mathrm{hB}}$ & $19.6 \pm 1.2^{\mathrm{gB}}$ & $22.6 \pm 0.5^{\mathrm{hAB}}$ & $26.0 \pm 2.0^{\mathrm{gA}}$ \\
3.90 & $31.2 \pm 0.2^{\mathrm{eB}}$ & $42.0 \pm 2.0^{\mathrm{gA}}$ & $26.6 \pm 0.2^{\mathrm{fC}}$ & $33.4 \pm 0.3^{\mathrm{gB}}$ & $41.0 \pm 1.0^{\mathrm{fA}}$ \\
7.81 & $38.0 \pm 0.1^{\mathrm{dC}}$ & $55.6 \pm 0.4^{\mathrm{fA}}$ & $36.6 \pm 1.0^{\mathrm{eC}}$ & $46.5 \pm 2.2^{\mathrm{fB}}$ & $54.0 \pm 3.0^{\mathrm{eA}}$ \\
15.6 & $36.3 \pm 3.2^{\mathrm{dD}}$ & $60.3 \pm 0.2^{\mathrm{eA}}$ & $49.3 \pm 0.6^{\mathrm{dC}}$ & $54.7 \pm 0.6^{\mathrm{eB}}$ & $62.0 \pm 0.0^{\mathrm{dA}}$ \\
31.2 & $47.3 \pm 0.1^{\mathrm{cC}}$ & $71.6 \pm 2.2^{\mathrm{dA}}$ & $51.6 \pm 0.2^{\mathrm{dC}}$ & $64.2 \pm 0.8^{\mathrm{dB}}$ & $72.0 \pm 0.80^{\mathrm{cA}}$ \\
62.5 & $50.0 \pm 0.0^{\mathrm{cC}}$ & $77.6 \pm 0.2^{\mathrm{cA}}$ & $59.3 \pm 1.0^{\mathrm{cC}}$ & $77.6 \pm .5^{\mathrm{cA}}$ & $81.3 \pm 0.2^{\mathrm{bA}}$ \\
125 & $58.6 \pm 2.1^{\mathrm{bC}}$ & $85.6 \pm 0.4^{\mathrm{bA}}$ & $69.3 \pm 0.2^{\mathrm{bB}}$ & $87.2 \pm 0.2^{\mathrm{bA}}$ & $89.0 \pm 0.4^{\mathrm{aA}}$ \\
250 & $65 \pm 0.0^{\mathrm{aC}}$ & $92.3 \pm 2.0^{\mathrm{aA}}$ & $76.3 \pm 0.3^{\mathrm{aB}}$ & $93.0 \pm 0.0^{\mathrm{aA}}$ & $89.3 \pm 3.1^{\mathrm{aA}}$ \\
\hline
\end{tabular}

Different letters in the same column (lower case) and in the same row (upper case) represents significant differences at $\mathrm{p}<0.05$

However, the adhesion of pathogenic bacteria was reduced at the same concentration $(250 \mu \mathrm{g} / \mathrm{mL})$ to $72.7,69.0,63.7,47.3$, and $45 \%$ for C. albicans, K. Pneumoniae, P. mirabilis, S. pneumonia, and S. aureus respectively by glycolipid fraction (Table 4). The anti-adhesive activity of lipopeptide and glycolipid fractions isolated from L. acedophillus and L. pentousus respectively against $K$. pneumonia was similar to that obtained by biosurfactant isolated from L. fermentum and $L$. rhamnosus which prevented the adhesion of K.pneumoniae by 100\% [19]. This study is in agreement with the study by Gudina et al [12] which showed the highest anti-adhesive activity (100\%) against $S$. aureus and C. Albicans. This study concluded that the biosurfactant from $L$. acedophillus and L. pentousus had higher antiadhesion against test pathogens which could interfere with the adhesion of the pathogenic bacteria and fungus to surfaces. Rodrigues et al [20] showed that biosurfactants are able to alter the physicochemical properties of the surface to minimise the force of attraction between microorganisms and the surface of the biomaterial. Walencka et al [21] stated that the biosurfactant s affected bacterial surface interactions by the alterations in ST and bacterial cell-wall charge.

Table 4: Anti-adhesion activity of glycolipid against test pathogens

\begin{tabular}{cccccc}
\hline $\begin{array}{c}\text { Glycolipid } \\
(\boldsymbol{\mu g} / \mathbf{m l})\end{array}$ & P.mirabilis & S. aureus $^{\text {Pathogen }}$ & S.pneumoniae $^{\text {K. }}$ & $\boldsymbol{K}_{\text {Pneumoniae }}$ & C.albicans $^{\text {Pne }}$ \\
\hline 1.95 & $17.0 \pm 0.2^{\mathrm{fA}}$ & $3.6 \pm 0.1^{\mathrm{fC}}$ & $9.0 \pm 0.0^{\mathrm{gB}}$ & $11.8 \pm 0.2^{\mathrm{gB}}$ & $3.5 \pm 0.0^{\mathrm{gC}}$ \\
3.90 & $22.3 \pm 0.5^{\mathrm{eA}}$ & $8.5 \pm 4.0^{\mathrm{eC}}$ & $15.5 \pm 0.5^{\mathrm{fB}}$ & $25.0 \pm 0.2^{\mathrm{fA}}$ & $9.9 \pm 0.1^{\mathrm{fC}}$ \\
7.81 & $34.8 \pm 1.0^{\mathrm{dA}}$ & $11.0 \pm 0.3^{\mathrm{deB}}$ & $15.0 \pm 0.3^{\mathrm{fB}}$ & $34.0 \pm 0.4^{\mathrm{eA}}$ & $12.0 \pm 0.0^{\mathrm{fB}}$ \\
15.6 & $37.6 \pm 1.0^{\mathrm{dA}}$ & $14.0 \pm 0.7^{\mathrm{dC}}$ & $21.0 \pm 0.0^{\mathrm{eB}}$ & $39.7 \pm 0.2^{\mathrm{dA}}$ & $17.0 \pm 0.0^{\mathrm{eBC}}$ \\
31.2 & $44.3 \pm 0.1^{\mathrm{cA}}$ & $22.0 \pm 0.0^{\mathrm{cC}}$ & $27.7 \pm 1.0^{\mathrm{dB}}$ & $44.0 \pm 0.1^{\mathrm{cA}}$ & $30.0 \pm 0.9^{\mathrm{dB}}$ \\
62.5 & $49.0 \pm 0.0^{\mathrm{bB}}$ & $24.0 \pm 0.5^{\mathrm{cD}}$ & $32.0 \pm 0.2^{\mathrm{cC}}$ & $56.0 \pm 0.0^{\mathrm{bA}}$ & $50.4 \pm 0.3^{\mathrm{cB}}$ \\
125 & $53.0 \pm 0.0^{\mathrm{bB}}$ & $35.0 \pm 0.1^{\mathrm{bC}}$ & $38.5 \pm 0.4^{\mathrm{bC}}$ & $57.6 \pm 0.3^{\mathrm{bB}}$ & $64.0 \pm 0.1^{\mathrm{bA}}$ \\
250 & $63.7 \pm 1.0^{\mathrm{aB}}$ & $45.0 \pm 0.0^{\mathrm{aC}}$ & $47.3 \pm 0.1^{\mathrm{aC}}$ & $69.0 \pm 0.0^{\mathrm{aA}}$ & $72.7 \pm 0.6^{\mathrm{aA}}$ \\
\hline
\end{tabular}

Different letters in the same column (lower case) and in the same row (upper case) represent significant differences at $\mathrm{p}<0.05$

\section{Anti-Biofilm Activity Of Biosurfactant Fractions Against Test Pathogens}

There has been increased resistance shown by biofilms towards drug therapy, and disinfections.

Biofilms aid pathogens in avoiding host immune responses, will lead to chronic infections [22] It was demonstrated that, incidence of ant biofilm activity among biosurfactants should impact the 
Abdalsadiq et al RJLBPCS $2018 \quad$ www.rjlbpcs.com Life Science Informatics Publications expression of bacteria virulence factors, which are essential during infection because they disturb cell to cell signaling. Therefore, preliminary bacterial adhesion and subsequent biofilm formation can be prevented by lipopeptide and fraction [2]. The lipopeptide and glycolipid fractions were analysed for their anti-biofilm activity against pathogenic organisms. Results clearly show that the anti-biofilm activity rises as the concentration of the fractions increases. This study showed that lipopeptide fraction was powerfully penetrate the biofilm and kill microorganisms with highest effectiveness up to $100 \%$ against K. Pneumoniae and P. mirabilis, 97.3\% against C. albicans, $88.7 \%$ against $S$. pneumoniae, and $85 \%$ against $S$. aureus (Table 5).

Table 5: Anti-biofilm activity of lipopeptide against test pathogens

\begin{tabular}{|c|c|c|c|c|c|}
\hline $\begin{array}{l}\text { Lipopeptide } \\
(\mu \mathrm{g} / \mathrm{ml})\end{array}$ & P.mirabilis & S. aureus & $\begin{array}{c}\text { Pathogen } \\
\text { S.pneumoniae }\end{array}$ & K. Pneumoniae & C.albicans \\
\hline 1.95 & $32.3 \pm 0.0^{\mathrm{fB}}$ & $32.0 \pm 0.1^{\mathrm{hB}}$ & $37.0 \pm 0.0^{\mathrm{hA}}$ & $41.9 \pm 0.05^{\mathrm{eA}}$ & $29.0 \pm 0.0^{\mathrm{gB}}$ \\
\hline 3.90 & $38.0 \pm 0.0^{\mathrm{eC}}$ & $41.0 \pm 0.1^{\mathrm{gBC}}$ & $44.1 \pm 0.5^{\mathrm{gB}}$ & $56.0 \pm 2.0^{\mathrm{dA}}$ & $52.0 \pm 0.5^{\mathrm{fA}}$ \\
\hline 7.81 & $42.0 \pm 0.5^{\mathrm{eC}}$ & $47.5 \pm 0.1^{\mathrm{fB}}$ & $51.0 \pm 0.4^{\mathrm{fB}}$ & $56.0 \pm 0.8^{\mathrm{dA}}$ & $57.0 \pm 0.5^{\mathrm{eA}}$ \\
\hline 15.6 & $52.9 \pm 0.4 \mathrm{dC}$ & $56.0 \pm 0.0^{\mathrm{eC}}$ & $61.3 \pm 0.6^{\mathrm{eB}}$ & $73.4 \pm 0.6^{\mathrm{cA}}$ & $65.4 \pm 2.0^{\mathrm{dB}}$ \\
\hline 31.2 & $65.0 \pm 0.0^{\mathrm{cC}}$ & $67.0 \pm 0.0^{\mathrm{dC}}$ & $66.8 \pm 0.1 \mathrm{dC}$ & $77.3 \pm 0.1^{\mathrm{cA}}$ & $71.0 \pm 0.8^{\mathrm{cB}}$ \\
\hline 62.5 & $89.0 \pm 0.0^{\mathrm{bA}}$ & $72.1 \pm 0.1^{\mathrm{cD}}$ & $77.9 \pm 0.6^{\mathrm{cC}}$ & $83.0 \pm 0.05^{\mathrm{bB}}$ & $83.3 \pm 0.9^{\mathrm{bB}}$ \\
\hline 125 & $99.9 \pm 0.2^{\mathrm{aA}}$ & $78.5 \pm 0.4^{\mathrm{bC}}$ & $82.7 \pm 0.7^{\mathrm{bC}}$ & $97.2 \pm 2.2^{\mathrm{aA}}$ & $86.4 \pm 0.02^{\mathrm{bBC}}$ \\
\hline 250 & $100 \pm 0.0^{\mathrm{aA}}$ & $85.3 \pm 0.2^{\mathrm{aB}}$ & $88.7 \pm 0.1^{\mathrm{aB}}$ & $100.0 \pm 0.6^{\mathrm{aA}}$ & $97.3 \pm 0.1^{\mathrm{aA}}$ \\
\hline
\end{tabular}

Different letters in the same column (lower case) and in the same row (upper case) represents significant differences at $\mathrm{p}<0.05$.

However, the effect of glycolipid fraction was much stronger on $S$. aureus (100\%) followed by $K$. Pneumoniae (76.3\%), C. albicans, (68.7\%), S.pneumoniae (44.3\%) and P. mirabilis $(31.7 \%)$ (Table 6), a significantly $(\mathrm{p}<0.05)$ decreased level of biofilm formation in all tested pathogens when compared to control.

Table 6: Anti-biofilm activity of glycolipid against test pathogens

\begin{tabular}{llllll}
\hline $\begin{array}{l}\text { Glycolipid } \\
(\boldsymbol{\mu g} / \mathbf{m l})\end{array}$ & P.mirabilis & S. aureus & P.pneumoniae & K. Pneumoniae & C.albicans \\
\hline 1.95 & $8.9 \pm 0.1^{\mathrm{dD}}$ & $32.4 \pm 0.3^{\mathrm{fA}}$ & $12.7 .0 \pm 0.3^{\mathrm{dC}}$ & $16.1 \pm 0.1^{\mathrm{fBC}}$ & $19.0 \pm 0.0^{\mathrm{eB}}$ \\
3.90 & $14.0 \pm 0.0^{\mathrm{cC}}$ & $33.2 \pm 2.5^{\mathrm{fA}}$ & $23.0 \pm 0.0^{\mathrm{cB}}$ & $20.1 \pm 1.0^{\mathrm{eB}}$ & $35.0 \pm 0.3^{\mathrm{dA}}$ \\
7.81 & $17.5 \pm 0.1^{\mathrm{cC}}$ & $40.9 \pm 0.2^{\mathrm{eA}}$ & $26.5 \pm 0.1^{\mathrm{bcB}}$ & $23.0 \pm 0.0^{\mathrm{deB}}$ & $42.0 \pm 0.9^{\mathrm{cA}}$ \\
15.6 & $23.3 \pm 0.2^{\mathrm{bE}}$ & $57.1 \pm 0.6^{\mathrm{dA}}$ & $30.0 \pm 0.0^{\mathrm{bD}}$ & $37.5 \pm 0.2^{\mathrm{dC}}$ & $51.2 \pm 0.1^{\mathrm{bB}}$ \\
31.2 & $25.0 \pm 0.3^{\mathrm{abE}}$ & $68.5 \pm 0.0^{\mathrm{cA}}$ & $38.0 \pm 0.0^{\mathrm{aD}}$ & $44.5 \pm 0.1^{\mathrm{cC}}$ & $55.1 \pm 1.0^{\mathrm{bB}}$ \\
62.5 & $30.0 \pm 0.0^{\mathrm{aD}}$ & $88.0 \pm 0.5^{\mathrm{bA}}$ & $41.6 \pm 0.0^{\mathrm{aC}}$ & $62.0 \pm 0.0^{\mathrm{bB}}$ & $66.0 \pm 2.0^{\mathrm{aB}}$ \\
125 & $31.3 \pm 0.1^{\mathrm{aE}}$ & $97.5 \pm 0.7^{\mathrm{aA}}$ & $42.3 \pm 0.4^{\mathrm{aD}}$ & $75.4 \pm 0.4^{\mathrm{aB}}$ & $66.0 \pm 0.0^{\mathrm{aC}}$ \\
250 & $31.7 \pm 0.6^{\mathrm{aE}}$ & $100 \pm 0.0^{\mathrm{aA}}$ & $44.3 \pm 0.9^{\mathrm{aD}}$ & $76.3 \pm 1.0^{\mathrm{aB}}$ & $68.7 \pm 1.0^{\mathrm{aC}}$ \\
\hline
\end{tabular}

Different letters in the same column (lower case) and in the same row (upper case) represent significant differences at $\mathrm{p}<0.05$

Similarly lipopeptide biosurfactant from the L. acidophilus was able to interfere with the adhesion and biofilm formation by $S$. mutans, resulting in shorter chains formation. Also, many characteristics of $S$. mutans cells (adhesion ability, biofilm formation, surface properties, and gene expression) were modified due to treatment with L. acidophilus biosurfactant. A patent has been approved for Lactobacillus biosurfactants ability to prevent the adhesion of bacterial pathogens and their colonising of medical devices specifically to avoid urogenital infection in mammals [23]. Results of this study concur with an earlier report by Fracchia et al [24] which (C) 2018 Life Science Informatics Publication All rights reserved 

stated that, biosurfactants synthesised by Lactobacillus could inhibit biofilm formation of E. coli, S. aureus, S. arizonae and L. monocytogenus. Similarly, Ali [25] demonstrated that the biosurfactant isolated from L. acidophilus inhibits biofilm formation by P. Mirabilis. The glycolipid biosurfactant adheres to the pathogen cell surface and degrades the cell membrane and also breaks down its nutrition cycle. It is possible due to the amphiphilic nature of biosurfactant $\mathrm{s}$, fatty acid component of biosurfactant get incorporated into cell membrane and causing an increase in the size of cell membrane. This leads to a change in the ultra structure of cell such as ability to interiorise plasma membrane [2]. In this study, percentage of $C$. albicans biofilm inhibition by glycolipid fraction was $68.7 \%$ at concentration $250 \mu \mathrm{g} / \mathrm{ml}$, which was lower than those inhibited C. albicans biofilm (70\%) by rhamnolipid biosurfactant s from P. aeruginosa at concentration of $5000 \mu \mathrm{g} / \mathrm{ml}$. The effect of glycolipid from this study on bacterial biofilm was also much stronger S. aureus $100 \%)$ at lower concentration $(250 \mu \mathrm{g} / \mathrm{ml})$ compared to rhamnolipid which reduced the biofilm formation by $50 \%$ at concentration $500 \mu \mathrm{g} / \mathrm{mL}$ [26]. The encouraging results obtained against biofilm producer strains make this biosurfactant a good candidate to prevent adhesion on plastic surfaces. The lipopeptide and glycolipid from Lactobacillus Spp. not only exhibits antimicrobial activity but also hinders biofilm formation.

\section{CONCLUSION}

The biosurfactant fractions (lipopeptide and glycolipid) exhibited antimicrobial, anti-adhesion and anti-biofilm activity as assessed using the disc diffusion method, MIC, anti-adhesion assay and anti-biofilm assay. The lipopeptide fraction exhibited stronger antimicrobial at lower MIC values ranging from 7,81 to $62.5 \mu \mathrm{g} / \mathrm{ml}$ while glycolipid fraction exhibited bioactivity against pathogenic bacteria at MIC values ranging from 15.6 to $62.5 \mu \mathrm{g} / \mathrm{ml}$. The lipopeptide fraction was strongest as antiadhesion and anti-biofilms agent against pathogens at a concentration of $250 \mu \mathrm{g} / \mathrm{ml}$ compared with glycolipid fraction. There is a need for new strategies to control extreme biofilm antibiotic resistance by developing new therapies for the purpose of disrupting biofilms and destroying the constituent bacteria. Therefore, the treatment with biosurfactant from L. acedophillus and $L$. pentousus could offer an alternative way to control biofilm development and also have an antiadhesion effect on bacterial pathogens.

\section{CONFLICT OF INTEREST}

None

\section{ACKNOWLEDGEMENT}

The authors would like to thank the Faculty of Science and Technology, Universiti Sains Islam Malaysia for their support.

\section{REFERENCES}

1 Desai JD, Banat IM. Microbial production of Surfactants and Their Commercial potential. Microbiology and Molecular Biology Reviews. 1997; 61: 47- 64.

(C) 2018 Life Science Informatics Publication All rights reserved Peer review under responsibility of Life Science Informatics Publications 
2 Rodrigues LR, Teixeira JA. Biomedical and therapeutic applications of biosurfactants In R. Sen (eds), Biosurfactants. Advances in experimental medicine \& biology series. Landes Bioscience Publishers, Austin, Texas, United States.2010.(ISBN: 978-1-4419-5978-2). 7587.

3 Ron E, Rosenberg E. Natural roles of biosurfactants. Environmental Microbiology.2001:3: 229-236.

4 Gan BS, Kim J, Reid G, Cadieux P, Howard JC. Lactobacillus fermentum RC-14 inhibits Staphylococcus aureus infection of surgical implants in rats. J Infect Dis. 2002; 185(9): 1369-1372.

5 Rasmussen TB, Givskov M. Quorum sensing inhibitors: A bargain of effects. Microbiology. 2006; 152: 895-904.

6 Rodrigues L R, Banat IM, Teixeira J, Oliveira R. Strategies for the prevention of microbial biofilm formation on silicone rubber voice prostheses. J Biomed Mater Res Part B-Appl Biomater. 2007; 81: 358-370.

7 Douglas LJ. Candida biofilms and their role in infection. Trends in Microbiology. 2003; 11: 30-36.

8 Nikolaev YA, Plakunov VK. Biofilm-city of microbes or an analogue of multicellular organisms? Microbiology. 2007; 76: 125-138.

9 Mukherjee PK, Chandra J. Candida biofilm resistance. Drug Resistance Updates. 2004; 7: 301-309.

10 Das P, Mukherjee S, Sen R. Antimicrobial potential of a lipopeptide biosurfactant derived from a marine Bacillus circulans. J. Appl. Microbiol. 2008; 104: 1675-1684.

11 Scorzoni L, Benaducci T, Almeida AMF, Silva DHS, Bolzani VS, Mendes-Giannini, MJS. Comparative study of disk diffusion and microdilution methods for evaluation of antifungal activity of natural compounds against medical yeasts Candida spp and Cryptococcus sp. Revista de Ciencias Farmaceticas Basica e Aplicada. 2007; 28(1): 25-34.

12 Gudina EJ1, Rocha, V, Teixeira, JA, Rodrigues LR. Antimicrobial and antiadhesive properties of a biosurfactant isolated from Lactobacillus paracasei ssp. paracasei A20. Lett Appl Microbiol. 2010; 50(4): 419-24.

13 Peeteres E, Nelis HJ, Coenye T. Copmparison of multiple methods for quantification of microbial biofilms grown in microtiter plates. Journal of microbiological methods. 2008; 72:157-165.

14 Varnier AL, Sanchez L, Vatsa P, Boudesocque L, Garcia-Brugger A, Rabenoelina F, Dorey S. Bacterial rhamnolipids are novel MAMPs conferring resistance to Botrytis cinerea in grapevine. Plant, Cell \& Environment. 2009; 32(2): 178-193.

(C) 2018 Life Science Informatics Publication All rights reserved Peer review under responsibility of Life Science Informatics Publications 
15 Grover M, Nain L, Singh S B, Saxena A K. Molecular and biochemical approaches for characterization of antifungal trait of a potent biocontrol agent Bacillus subtilis RP24. Current Microbiology. 2010; 60: (2) 99-106.

16 Pandey B, Ghimire P, Agrawal VP. International conference on the great himalayas: climate, health, ecology, management and conservation, kathmandu. Organized by Kathmandu University and the Aquatic Ecosystem Health and Management Society, Canada. 2004.

17 Rodrigues L R, Mei HC, Teixeira J, Oliveira R. Influence of biosurfactants from probiotic bacteria on formation of biofilms on voice prostheses. Appl. Environ. Microbiol. 2004; 70 (7): 4408-10.

18 Salman JAS, Khalaf KJ, Al-Marjani MF. Study of inhibitory agents produced by Streptococcus thermophiles on growth and biofilm formation for some pathogenic bacteria. Journal of biotechnology research center. 2013; 7(2): 24-31.

19 Brzozowski B, Bednarski W, Golek P. The adhesive capability of two lactobacillus strains and physicochemical properties of their synthesized biosurfactants. Food technol. Biotechnol. 2011; 49 (2): 177-186.

20 Rodrigues L, Banat IM, Teixeira J, Oliveira R. Biosurfactants: potential applications in medicine. J Antimicrob Chemother. 2006; 57(4): 609-618.

21 Walencka E, Rozalska S, Sadowska B, Rozalska B. The Influence of Lactobacillus acidophilus-Derived Surfactants on Staphylococcal Adhesion and Biofilm Formation. Folia Microbiol. 2008; 53(1): 61-66.

22 Cerca N, Jefferson KK. Effect of growth conditions on poly-N acetylglucosamine expression and biofilm formation in Escherichia coli. FEMS. Microbiol. Lett. 2008; 283(1): 36-41.

23 Carrillo-Castaneda G, Juarez MJ, Peralta-Videa JR, Gomez E, Gardea Torresdey JL. Plant growth promoting bacteria promote copper and iron translocation from root to shoot in alfalfa seedlings. Journal of Plant Nutrition. 2003; 26: 1801-1814.

24 Fracchia L, Cavallo M, Allegrone G. Martinotti MG. A Lactobacillus-derived biosurfactant inhibits biofilm formation of human pathogenic Candida albicans biofilm producers. Appl Microbiol Biotechnol. 2010; 2: 827-837.

25 Ali OA. Prevention of proteus mirabilis biofilm by surfactant solution. Egypt. Acad. J. Biolog. Sci. 2012; 4(1): 1- 8.

26 Singh N, Pemmaraju SC, Pruthi PA, Cameotra SS, Pruthi V. Candida biofilm disrupting ability of dirhamnolipid (RL-2) produced from Pseudomonas aeruginosa DSVP20. Appl Biochem Biotechnol. 2013; 169: 2374-2391.

(C) 2018 Life Science Informatics Publication All rights reserved Peer review under responsibility of Life Science Informatics Publications 